\title{
Women Entrepreneurship and Women Enterprise Management in Karachi
}

\author{
Faryal Salman and Dr. Mustaghis-ur-Rahman \\ SZABIST \\ Karachi, Pakistan
}

\begin{abstract}
This study is on "Women Entrepreneurship and Women Enterprise Management in Karachi". The basic purpose of this study is to explore general information about the women entrepreneurs and the challenges they face at the time of establishing their business. The findings of this study helps us understand that why, despite having the talents and ambitions, these women entrepreneurs face a number of challenges that hampers the growth, success and prosperity of their businesses. In the light of the findings of this research, there is a need to create supportive business environment and networking with business and non-governmental organizations to develop and mobilize women to the business sector through their own enterprises. This would not only lead to financial independence of women but also will have a multiplier effect as a result of overall well being of the society.
\end{abstract}

Keywords: Women entrepreneurs, women empowerment, women enterprises

\section{INTRODUCTION}

There has been a great deal of attention paid to the subject of entrepreneurship over the past few years, stemming primarily from the discovery by economic analysts that small firms contribute considerably to economic growth and vitality. Moreover, many people have chosen entrepreneurial careers because doing so seems to offer greater economic and psychological rewards than does the large company route. The entrepreneur is the key to the successful launch of any business. Presently, both men and women operate enterprises. The enterprises operated by women are known as "women enterprises". Although, throughout the world, the number of women owned enterprises are increasing day by day; but in Pakistan, their significance has not been accepted so far. This is the reason women entrepreneurship management is a difficult task for women here.

Women entrepreneurship can be a way to women's empowerment. In Pakistan, women can be an important source for economic development, provided their potentials are utilized in manufacturing and service sector, apart from engaging them mostly in agricultural based activities. Not providing economic opportunities to women deprives the country of a major source of earning and wastage of very productive labor force.
A solution to the problem of economic recession in Pakistan is economic empowerment of women. This can be done through creating employment opportunities and income generation activities for women to enable them to survive, prosper and provide support for their families. Women are more concerned for the over all well-being of their children in terms of their health, education and other needs. If they have a smooth stream of income and are independent in their decision-making, it brings overall prosperity in the household and thus has a trickle down effect in the society. Thus, we can say that these women entrepreneurs can help in breaking the vicious circle of poverty.

Women entrepreneurs, who have to wrestle with a number of management issues to ensure smooth running of their business enterprises, are managing women enterprises. These issues are related to:

- Financial management

- Human resource management

- $\quad$ Production management

- $\quad$ Marketing management

- Quality control management

Through this research, we explore how the abovementioned management issues hamper the business activities of women entrepreneurs. One of the major reasons why women entrepreneurs in Pakistan face difficulties at management level is their lack of expertise, proper education and guidelines to tackle with these issues. In fa mily owned business, boys sit with their father from the very early childhood as business practices and management runs in their blood streams. Women, unfortunately do not get any such opportunity due to cultural restrictions that require girls to stay back home with mothers. It is only when they grow up or due to some economic need that these women take up enterprising activities and learn how to manage business at times by trial and error.

\section{ENTREPRENEURS AND ENTREPRENEURSHIP}

Many authentic definitions of entrepreneurship have been coined by eminent scholars and economists. One of the earliest definitions of entrepreneurship has been given

Journal of Independent Studies and Research (JISR) - Management and Social Sciences \& Economics

Volume 6, Number 2, July 2008 
by Smiths (1976), who has defined entrepreneurship as "The transformation of demand into supply for profits" [1]. Another entrepreneurship scholar 'Mill' has defined entrepreneurship as "Founding a private enterprise" [2]. Joseph Schumpeter's widely known definition for entrepreneurship is "Carrying out new combinations: later on termed innovation through the process of "creative destruction' i.e. old being washed by new one” [1].

This viewpoint of Schumpeter is supported by Peter Drucker who describes the entrepreneurial role as one of gathering and using resources. According to Drucker, these resources to produce results should be allocated to opportunities rather than to problems. It has been more than a decade of innovations in all area -- international affairs, politics, economics, technology, and business. However, this rapid acceleration of economic growth calls for even more innovation, especially from business and business executives. The only way a business can hope to prosper if not only to survive, is to innovate. It is the only way to convert change into opportunity [3].

\subsection{Entrepreneurship in Pakistan}

Before we focus on the topic of our research "Women Entrepreneurship and Women Enterprise Management in Karachi”, it is important to highlight the current entrepreneurship scenario in Pakistan. Through this we can identify the role, opportunities and challenges for female entrepreneurs.

Development, growth, employment generation and poverty eradication have all been standard goals of the economic policies, plans and programs of policy makers in Pakistan over the last six decades. International agencies were founded with the objective of achieving economic development and eradicating poverty. Sixty year's later poverty persists and many developing countries like Pakistan is in poverty trap. Economic growth requires institutional backup of:

a) Democratic institutions

b) Sound legal framework

c) Market regulation

d) Access to information

According to a report published by Pakistan Institute of Development Economics, in Pakistan, unfortunately, entrepreneurship has experienced "rent seeking culture". A handful of wealthy and powerful individuals, instead of making profits through trade or wealth creation, earn their fortunes by maneuvering economic environment. They also influence government actions, and policies for wealth multiplication, that results in restricting the number of players in the market [4].
Such a culture proves very discouraging especially for female entrepreneurs, since most of them with their limited resources are striving to make their presence felt in the male dominated economic world.

In Pakistan, enterprises have been restricted only to industries rather than small enterprises. Appallingly, since we experience a strong political hold on the public and private sector economic activities, therefore very little encouragement is given to entrepreneurs.

This phenomenon explains why we have not so successful entrepreneurial activities in the country despite all the talents and the unfavorable conditions for the nurturing of small scale manufacturing sector.

A number of factors are responsible for absence of innovation. Most of the businessmen want to be involved in their inherited business. They think it as secure and risk free. Sometimes, the innovation has been the result of some information advantage. This lack of innovation has confined women entrepreneurs to few traditional businesses, such as parlors, boutiques, Montessori etc.

\section{WOMEN ENTREPRENEURSHIP CONCEPTS AND PRACTICES}

Although women constitute half of world's population, yet they are the largest group, which is excluded from the benefits of social and economic development. Women constitute a strong labor force, which needs to be mobilized and encouraged. Women make great entrepreneurs; they are caring employers and at the same time diligent administrators. They manage to instill enthusiasm in all around them and are creative enough to come up with inspiring innovative ideas that are needed by the economy.

The issue of women's status, autonomy and equality has frequently been raised internationally on the premise that a nation cannot progress when a vast segment of society is deprived of its due share and not allowed to play its role properly. Economically empowering women results in not only their development but also has a trickle down effect and brings an overall prosperity in the economy.

\subsection{Women Entrepreneurship in the World}

The journey of women entrepreneurship began during 1960's and 70's. Significant business developments are taking place in the global economy of the 21st century. One is the explosion of women-owned businesses; the second is international trade. When these two go together,

Journal of Independent Studies and Research (JISR) - Management and Social Sciences \& Economics Volume 6, Number 2, July 2008 
it results in a powerful force contributing to economic growth, development, and prosperity in the world.

Today, women are starting businesses at twice the rate of men and becoming major forces, both in the traditional and the new global e-business marketplace.

In developed and advanced economies, women entrepreneurs are well equipped with management tools and more trained in the entrepreneur skills. The literacy rate is also high for women in these countries, and due to liberal society, culture and norms, they face less gender related and discrimination issues that might hinder their performance as entrepreneurs. Therefore, it results in many successful business ventures by these women entrepreneurs.

\subsection{Women Entrepreneurship in South Asia}

The geographical anatomy of South Asia is composed of couple of issues. The region is today considered amongst the poorest, least literate and bare minimum gender sensitive territories. According to a report titled "II Conceptual Framework: A Context of Women in South Asia” by Mahboob ul Haq Human Development Center, "One third of people in South Asia live in absolute poverty and the region has some 400 million illiterate adults and approximately 80 million malnourished children”. South Asian women are deprived of the basic human rights, and there is very little participation with men on an equal footing in economic activities. Women entrepreneurs constitute less than $10 \%$ of the total business entrepreneurs in South Asia [5].

Development of women entrepreneurship can indeed lead to greater economic autonomy and gender balance, increase in women's self-esteem and confidence, greater say in business decision-making in the family, in the community and thus empower them economically and socially. Apart from economic rationale, development of women entrepreneurship has a special appeal for empowering women in the countries like Bangladesh, Pakistan, and India, where gender discrimination is still acute and hence gender equality and equity constitute core development issues [6].

Women's empowerment is also seen as a way of reducing poverty and achieving sustainable development, as they are the disproportionately large segment of the rural poor in most of the developing countries of the AsiaPacific region. PAP (1995) adopted in the Fourth World Conference of the United Nations on Women Development states that women participation in economic activities is changing especially after the Beijing Declaration and increasingly large number of women is taking up entrepreneurial activities worldwide [7].

Broadly speaking, the women in South Asia face the following challenges in setting up of their own enterprises and then managing them efficiently [9]:
a) access to credit
b) access to market
c) access to training
d) access to net works

\subsection{Women Entrepreneurs in Pakistan: Challenges and Issues}

Pakistan's population of 160 million has the highest gender imbalance in the world with 92 women to hundred men (compared to 106 women to 100 men in most industrialized countries); it implies that $47.3 \%$ of the total population is women. The federal labor force survey mentions in its 2005-2006 report that the overall women employment rate is 20.14 percent, rural and urban areas women's participation 23.63 and $12.53 \%$ respectively [8]. Although the figures on women owned businesses are not available, it is estimated about $1 \%$ of the total local, national and multinational enterprises. Pakistan ranks high in gender inequality compared internationally [9].

Women in our society have to devote extensive amount of time to household maintenance and family care such as childcare, food preparation, subsistence farming and other domestic jobs. This, in turns, reduces their chances for entry into schooling, the labor market and other activities outside the house. Also many women here do not get any formal training to set up and manage their business that finally gives rise to a number of management related issues. Such a discriminatory attitude forestalls any chances of entrepreneurship activities among women. Even if they have to support the family, financially they would be expected to take up jobs rather than thinking of starting their own ventures; as starting up your own business requires financial investment and involves risk of failure. Another reason for low participation of women in economic activities of the country is their restricted mobility. Whenever leaving the house, they have to be necessarily accompanied by some male member of the household.

In Pakistan, it is also noted that most of the successful female entrepreneurs belong to extremely well off families, who started their ventures as a hobby and then later on took them as careers.

Journal of Independent Studies and Research (JISR) - Management and Social Sciences \& Economics Volume 6, Number 2, July 2008 
At present, a large number of women entrepreneurs are working in Pakistan. They have initiated their businesses and made them flourishing in the highly competitive environment. Most of them are involved in traditional businesses such as boutiques, parlors, and bakeries while some of them are in manufacturing, consultancies and service provision. However, the largest number of skilled women labor force is employed in garments and handicrafts sector. In general, urban women are better placed than those working in rural areas.

Briefly mentioned below are the issues and challenges women entrepreneurs in Pakistan face in the setting up and management of their enterprises. Unless these issues are not solved sincerely, one cannot expect the culture and practices of women enterprises to flourish in our country.
a) Mind set of the society
b) Access to finance
c) Lack of information
d) Lack of entrepreneurship training and business skills
e) Lack of marketing facilities
f) Non availability of support and guidance
g) Labor issues
h) Government policies, regulations \& departments

\subsection{Initiatives by the Government and Different Support Institutions for Women Entrepreneurs}

The World Bank gender country profile states that the status of women in Pakistan is among the lowest in the world. Women are house bound under the traditional veiling system. They form the largest unpaid workforce of the country. Development planning in Pakistan has so far not been so favorable towards welfare activities of women. Since the inception of Pakistan, 10 five years plans have been introduced in the country, each having some provisions for the women development and welfare. The Government of Pakistan signed the convention and the elimination of all forms of discrimination against women in 1995. A National Plan of Action (NPA) was prepared and issued in 1998 by the Ministry of Women Development, which detailed the strategic objectives for the betterment and enhancement of women [10]. The government of Pakistan and Pakistani NGOs participated in Beijing plus five meetings in New York and formed basis for future actions to improve the plight of women in Pakistan [11]. Pakistan has witnessed a number of micro credit initiatives for its female borrowers. Example includes the Pakistan Poverty Alleviation Fund, PPAF; the National Rural Support Program, NRSP; other Rural Support Programs, RSPs; and more recently, Khushali
Bank. Apart from these institutions, First Women Bank Limited and SMEDA are participating in promoting enterprise culture among the women folk of Pakistan. Women Chamber of Commerce and Industry was founded in 2003. Its aim was to economically empower women and to help women gain access and control over capital, credit and other resources; and make women the owners and managers of small, medium and large enterprises. Since the restoration of democracy and a more flexible attitude towards women economic and entrepreneurial activities, some of the NGOs have been doing worth-mentioning efforts.

The present Government is committed to upholding the constitution rights for women as envisaged in Article 25 \& 34 of The Constitution of Pakistan, and make the utmost efforts to bring women into main stream society. Recently, $4^{\text {th }}$ International Conference on Women's Leadership was organized in Karachi from $23^{\text {rd }}$ till $25^{\text {th }}$ May 08 [12]. The theme of the conference was "The Power to Empower Women". The main topics discussed were: Political Empowerment of Women, Economic Empowerment of Women, and Women Empowerment supported by the World Association for Small \& Medium Enterprises (WASME) \& Karachi Chamber of Commerce \& Industry (KCCI). The conference was organized by the Sindh Women Development Department in collaboration with Karachi Chamber of Commerce \& Industry. The main purpose and conference vision was developing, empowering and connecting leaders and bringing strong, authentic and feminine leaders with a global perspective which inspires and guides communities, corporations, supranational institution, political organizations and entrepreneurship worldwide [13].

\section{DATA ANALYSIS AND FINDINGS}

The finding of this study is that the women entrepreneurs, in general, are increasing in number throughout the world. However, in Karachi, women entrepreneurs are not having significant role in the economic activity. There are many reasons for the insignificant role of women entrepreneurs. Some of them found through this study are as follows.

Information was gathered about the issues and challenges regarding the enterprise setup. More than half (53\%) of the sample women entrepreneurs acknowledged the main reason for starting their own business was utilizing their spare time. Also, more than half (60\%) of women entrepreneurs had support from their families and friends, especially husbands, in setting up their business. There has been a very limited role of the Government or any financial institutes in the setting up of business enterprise. Overwhelming majority (73\%) respondents said that they had set up their businesses with the help of

Journal of Independent Studies and Research (JISR) - Management and Social Sciences \& Economics Volume 6, Number 2, July 2008 
finances provided by their husbands/friends or other family members. However, some respondents (27\%) have established their businesses with their own savings. These women entrepreneurs said that once their businesses are established and they have earned credibility, then obtaining credit/loans from banks became easy. Mixed responses were filed with regard to the question as to the type of issues women entrepreneurs encountered at the time of establishment of business. Less than half (40\%) respondents faced no issues, as the male members of their family dealt most of them. While the other, less than half (40\%) acknowledged that the major issue was finding good, trust worthy staff. Regarding the driving force behind entering into the field of business, more than a quarter $(27 \%)$ respondents said that it was a matter of proving their talents. The other more than a quarter (27\%) respondents said they did not like the male dominated work environment, so opted to start their own business.

The sample women entrepreneurs were asked questions related to enterprise management. About having a formal hiring procedure, A large majority (73\%) respondents said that they had no hiring procedures and they had set certain criteria of hiring and any one, who fits in, is given the job. Great majority, (73\%) respondents said that they had no human resource management system. The entrepreneur herself conducted all the activities of HR. Less than half (47\%) respondents had a financial flow chart that was the case in partnership businesses. More than half (53\%) respondents were sole proprietor, so they had no financial flow chart. Marketing is the most essential activity for business firm. More than half (53\%) respondents said that they performed all the marketing themselves. Only less than half (47\%) had hired people who performed marketing functions. Administrative procedures are very important for smooth running of the business. Less than half (47\%) respondents had hired administrators in their organization. On contrary, more than half (53\%) respondents carried the administrative activities on their own. Quality control of products and services is most essential for the survival of an organization. Great majority (87\%) respondents said that it was their hundred percent involvements in the business that guaranteed consistent quality of their products and services. Some women entrepreneurs did purchasing of raw material on their own and did not trust any one. Women entrepreneurs were asked to identify management challenge areas. More than Half (67\%) respondents said that finding good, trustworthy people was very difficult. There is very low loyalty especially among the labor class and they leave the jobs on even a slightly higher offer. It was difficult training people and when they went, they took with them trade secrets that could be beneficial to the competitors.
Despite all the odds, the women enterprises are operating visibly in the fields of:

- Beauty parlors

- Schools/ Montessori’s

- Boutiques

- Furniture

- Manufacturing

- $\quad$ Ready made garments

- Jewelers

- Event management

- Food catering

- Restaurants

\section{CONCLUSION}

When taking up this research study, the researcher was very enthusiastic about women entrepreneurship and the system of the management of their enterprises. The main aspiration behind this study was number of female entrepreneurs who are running their own businesses and the desire to see the mechanism of their working. Also there was a need to have an insight into the issues they faced while managing their businesses.

While extensive literature review was conducted, the researcher came across a couple of interesting studies. The study conducted by Nabeel Goheer on "Women Entrepreneurship in Pakistan: How to Improve Their Bargaining Power" and Schumpeter's definition of entrepreneurship as the process of "Carrying out new combinations: later on termed innovation through the process of 'creative destruction' i.e. old being washed by new one", formed the basis of interest.

With no previous studies conducted on women entrepreneurs and women enterprise management in Karachi, the task of conducting research was cumbersome. After this study, it has been found that women entrepreneurs had a lot of potentials and were successfully operating their enterprises on the self help basis. However, most of these entrepreneurs needed technical guidance in management skills that could make them more successful and expand their business. Also, some boost is required so these women entrepreneurs can make the best use of their talents and make full contribution in the economic growth of the country. This will not only result in the economic development of women but also bring an overall prosperity in the society.

\section{RECOMMENDATIONS}

The economic participation of women, i.e. their presence in the workforce in quantitative terms, is important not only for lowering the disproportionate levels

Journal of Independent Studies and Research (JISR) - Management and Social Sciences \& Economics Volume 6, Number 2, July 2008 
of poverty among women, but also an important step towards raising household income and for encouraging economic development in the country as a whole.

Following are the steps recommended to promote women enterprises and women entrepreneurship:

There is a need to restore their confidence so these women entrepreneurs can openly share their experiences. Ministry of Women Development, Sindh, is running a daycare facility for the children of working women. If similar facilities are provided to women entrepreneurs, they can concentrate on their business without worrying about domestic chores and their children. Government can also encourage women entrepreneurs by providing small loans and micro credit, packages of soft skills, and supportive environments. The package of soft skills may include training of the basic managerial skills that ensures smooth running of the business. The supportive environment is also necessary as it helps identification of sources of fund, availability of raw material at subsidized prices, identification of markets-locally/internationally, provision of quality control and tax holidays on the products by women entrepreneurs.

SMEDA can play a very useful role in encouraging women entrepreneurs as most of these women entrepreneurs are operating on small and medium scale. The authority can conduct training workshops and other supportive activities for women who wish to operate their own enterprises. It has been found that many women entrepreneurs do not have proper management systems in their businesses; therefore, it is recommended that these women entrepreneurs hire OD consultants.

\section{FUTURE AREAS OF THE RESEARCH}

As a result of this research, we have come across some areas that need further exploration. Following suggestions are made to extend the initial work from this study:

- Comparative study of women versus men entrepreneurship in Pakistan

- Research into Women Vocational Training Institutes operating in Pakistan

- Contribution of women entrepreneurs in the economic activities

- Impact assessment of women entrepreneurs on society

\section{REFERENCES}

[1] R, D., Hisrich, M. P. Peters, Entrepreneurship, New York, McGraw Hill, 2002, pp 10-11.

Journal of Independent Studies and Research (JISR) - Management and Social Sciences \& Economics Volume 6, Number 2, July 2008
[2] D, Holt, Entrepreneurship New Venture Creation, India, Prentice-Hall, January 2000, pp 15.

[3] P, Drucker, Innovation and Entrepreneurship, Butterworth Heinemann, 1999, pp 28-29.

[4] N, Haq, K, Idrees, S, Ahmad, "Entrepreneurship in Pakistan”, www.pide.org.pk, 2007, Oct. 23 ${ }^{\text {rd }}, 2007$.

[5] M, Haq Human Development Centre "Women Entrepreneurs in South Asia”, www.unescap.org/tid/publication/indpub2401_chap4. pdf -2000 , Oct. $24^{\text {th }}, 2007$.

[6] N, Goheer, "Women Entrepreneurs in Pakistan: How to Improve their Bargaining Power?" http://www.ilo.org/dyn/empent/docs.2003, Nov.2 ${ }^{\text {nd }}$, 2007.

[7] Beijing \& Beyond, Millennium Development Goals, National Consultative Conference, Karachi, $22^{\text {nd }}-23^{\text {rd }}$ September 2005, pp 14-15.

[8] Sustainable development policy institute, “Gender and globalization, http://www.spdi.org/reserachprogrmme/human Development/gender and organization.html\#1. 2006, Oct. $28^{\text {th }} 2007$.

[9] T. A, Saeedi. "Interview: Dr. Saeeda Malik, Minister of Women Development Sindh”, Pakistan \& Gulf Economists, Nov 05-11, 2007, Vol. XXVI, No. 45.

[10] National Plan of Action (NPA), Ministry of Women Development Social Welfare and Special Education September 1998.

[11]Beijing + 10 Pakistan, NPA Implementation, Coordination, Advocacy \& Communication, Government and NGO initiatives, May 2002-Jun 2003, pp 78-79.

[12]App. "Government committed to uphold women’s rights: Sherry Rehman,”The News”, 26 ${ }^{\text {th }}$ May 2008, City News, pp 20.

[13] “ $4^{\text {th }}$ International Conference on Women Leadership”, Karachi, www.womenleadershipconfernce.com/html Jun. ${ }^{\text {rd }}$, 2008. 